\title{
AC 2010-1605: ET CONTRIBUTION TO UNIVERSITY CORE CURRICULUM THROUGH A COURSE ON SUSTAINABILITY
}

\section{Anoop Desai, Georgia Southern University}

Dr. Anoop Desai received his BS degree in Production Engineering from the University of Bombay in 1999, and MS and Ph.D. degrees in Industrial Engineering from The University of Cincinnati in 2002 and 2006. His main research interests are in Product Lifecycle Management, Design for the Environment, Total Quality Management including tools for Six Sigma and Ergonomics. In addition to teaching ET courses in these fields, he is an instructor and co-developer of the core course described in the paper.

\section{Phil Waldrop, Georgia Southern University}

Phillip S. Waldrop, PhD, is a professor in the Department of Mechanical \& Electrical Engineering Technology at Georgia Southern University. He is a graduate of Ball State University; his graduate degrees are from Purdue University. In addition to manufacturing engineering- and industrial management-related courses, he teaches the university core course described in this paper. A former aerospace R\&D manager, he is Past-President of the Management Division of the Association of Technology, Management, and Applied Engineering, faculty advisor for student chapter S085 of the Society of Manufacturing Engineers, and a recipient of the 2010 SME Award of Merit. 


\title{
Contribution to University Core Curriculum through a Course on Sustainability
}

\begin{abstract}
This paper presents a case study of the development of a course focused on sustainability as part of the university core curriculum. This was an opportunity for an engineering technology department to contribute to the university core curriculum and to help fulfill its academic mission. The said course could be described as an elective in the general Math/Science/Technology area. The course is designed in such a way as to engage a broad range of students in the study of sustainability from a technical perspective and not a purely cultural viewpoint. The structure of the course intends to impart to all students, especially non majors (students who are non-science majors) an insight into current and past industrial practices that have been causative of pollution and generally unsustainable behavior. Simultaneously, it also offers insights into emerging and potential solutions to address sustainability issues from the engineering and technology perspective. One of the principal features of this course is the exploration of career opportunities for non-majors in the field of sustainability. This paper content and subsequent presentation will include an overview of course content and delivery techniques as well as its salient features.
\end{abstract}

\section{Introduction}

Sustainability can be defined as a pattern of human activity that can be pursued without degradation of the environment, society or the economy. Recently, an effort was undertaken at a university in the southeast United States to develop a course on global sustainability and innovation. It has been obvious for some time now that the earth has finite natural resources that cannot be replenished. Such resources include crude oil and natural gas, metal ores, natural habitat and clean and potable water. Not only is the situation not improving, it has been getting worse over time. This is no longer an issue of purely academic interest. It has managed to become a mainstream concern. In view of this fact, the authors felt that the time was opportune to offer a course on conservation and sustainability. Offering a global context to such a course, it was felt, would enhance its appeal.

Quite often, courses dealing with sustainability or environment management and conservation in general are offered by science departments. Said courses are generally exclusively offered to science students. This approach leaves out a major portion of the student body. Students who are not scientists in training have no access to a good on campus course on environmental conservation. The authors sought to rectify this situation by building a comprehensive course on sustainability offering it to all students from across campus. Access to this diverse student population was a key goal in designing the aforementioned course. It is often extremely difficult 
to design a truly multidisciplinary course. Content should be universally relevant to students within a full range of majors at the institution. This means that there must be something in it for everybody and it should all come together towards one goal: Sustainability.

The new course was termed: 'Global Sustainability and Innovation'. It was designed during the summer of 2009 and has been incorporated into the core curriculum as a science and technology elective. Its basic objective was to impart to students from across campus insights that issues, impacts and solution surrounding the concept of sustainability. In order to accomplish this objective, course content included material related to different aspects such as depletion and conservation of earth's natural resources, waste management and recycling and introduction to green concepts such as alternative energy sources, recycling, reuse and remanufacturing. A historic perspective and the role played by technology in bringing about change in people's lives was also examined.

The course is offered as a required course to all students across campus. Three sections of the course were taught in the fall of 2009. The total enrolment in all three sections was about 250 students. The student population was highly diverse with psychology, criminal justice, chemistry, engineering technology and undecided majors receiving substantial representation.

\section{Background}

TCGT 1530 entitled Science, Technology and the Environment had been a freshman level course at the concerned university with an annual enrolment of about 400 students. It had been part of the core curriculum for quite a few years and dealt primarily with different kinds of technologies and their role in human development. It also dealt only in passing with topics related to natural conservation and resource management. Being part of the core curriculum, this course offered the opportunity to serve as a gateway for students to become familiarized with issues related to 'technology'.

With the growing surge in environmental technology, and sustainability in particular, the authors felt that the time was right to update the content and to rename the course in order to accurately reflect its novel character. TCGT 1530 was modified and upgraded as follows;

1. More exposure was given to recent energy technology developments such as fuel cells, solar power, solar cells, and other non-traditional sources of energy

2. A high degree of coherence was developed between the new course content and individual topics so as to reflect technology as a system for facilitating sustainability.

3. The concept of product design and lifecycle was emphasized in the new course as it is directly related to sustainability

4. Because most sustainability and green design related content tends to largely ignore the economics of sustainability (a crucial component which depending on how it is dealt with can make or break the case for sustainability), the 'business case for sustainability' was emphasized as not only to making projects feasible but serving as an avenue for future employment as well. 
5. Method of course delivery has been changed from lecture only to incorporate more audio-visual material as well as student team based research activities. Additionally students engage in hands-on sustainability related activities on campus such as a campus re-lamping program organized by the office of sustainability. This enables students to become directly engaged in sustainability practice.

6. Sustainability is a multidisciplinary topic. Therefore, guest lectures from different departments such as Biology, Chemistry, Economics, interior design, architecture and civil engineering can be incorporated into the course content. This component has not been fully incorporated thus far but will be in the future. It is intended to impart to students a truly multidisciplinary feel for sustainability.

Today's students who consider themselves responsible members of the community want to find out the truth behind rising global temperatures, ocean levels, commodity prices etc. A redesigned TCGT 1530 strives to bring the course content abreast with the current state of the art in sustainability by encouraging students to think creatively, to look for solutions and to personally engage in its practice.

\section{Methodology}

The crux of the redesigned course is to inculcate in students the sense that sustainability is larger than recycling and tree hugging. It is more a way of thinking and doing so as to utilize as little of the earth's natural resources as possible. It has tried to achieve this objective through the use of critical thinking hands on projects within cross disciplinary teams. This approach has met with mixed success so far and we continue to monitor its progress. Students participate in teams of 4-5 and work on a project such as the advantages of solar power. They present their findings to the entire class and then engage in a debate with another team that has argued against solar power. This approach encourages students to sharpen their critical mental faculties. Upon completion, students taking 'Global sustainability and innovation' will be able to gain a degree of proficiency in the following skills:

\section{Sustainability}

- Define, compare, and contrast, the concepts and terminology pertaining to sustainability, technology, science and the applied sciences

- Critically examine the different parameters that contribute to sustainability

- Appreciate the effects that different forms of energy sources have on the environment

- Identify the various parameters that play a direct or indirect role in conservation of natural resources including land, water, food, atmosphere etc

- Objectively examine the business case for sustainability

\section{Technology:}

- Identify, describe, and illustrate characteristics of modern technology as related to sustainability 
- Identify, describe, and discuss scientific principles that relate to contemporary technologies, and environmental conditions

- Identify and discuss issues in: technology transfer, appropriate technology, environment, and global information systems.

- Review and discuss issues confronting scientists and technologists pertaining to our global energy resources, food resources and water resources

- Identify and describe innovations in: biotechnology, information technology, and manufacturing \& production enterprises.

- Discuss contemporary and emerging technologies.

- Discuss pertinent issues related to technology assessment.

- Define and discuss research and development as it relates to contemporary technology.

It is our intention to hopefully convince students that the environment is a fragile organism and have respect for the earth's finite natural resources. This should lead to appreciation of the fact that the earth has enough resources to satisfy everyone's need but not everyone's greed ${ }^{[1]-[4] .}$.t is also our intention to try and encourage students from non science/technology majors to get involved with the larger issue of sustainability. The course being part of the core curriculum affords a significant opportunity to tap this potential. It is accomplished through the use of cross disciplinary teams. A three pronged approach was used to design a method of instruction. This is detailed as follows.

- Instruction Methodology: Lectures as well as audio-visual techniques were used in facilitating instruction. Videos involved short films and documentaries that dealt directly with topics such as sustainability, energy sources, alternate energy, water conservation, hybrid cars, agriculture and food and the business case for sustainability.

- Creative problem solving through cross disciplinary groups: The class population is divided into small groups of 4-5students. The composition of each group is such that they all belong to different majors. Each group will seek to find creative solutions to solving problems pertaining to sustainability.

- Hands-on techniques to enhance problem solving: This component is comprised of teams of students (about 4-5) researching atopic. For instance one multidisciplinary group of students researches the advantages of electric cars. Another group explores the disadvantages of electric vehicles. Both groups are given about 2 weeks to conduct their research and prepare a presentation using power point or any combination of audio-visual media. They are assigned a specific date to present their findings and debate against each other for about 10 minutes. This presentation and debate is subjected to peer grading by other students in the class. This activity is assigned about $35 \%$ of the final grade and thus students are asked to assign it an appropriate amount of importance.

\section{Survey to reflect course enhancement}

The authors wish to asset that a comprehensive survey was prepared to compare the old version of TCGT 1530 with the enhanced version (as presented in this paper). The results of 
this survey have not been received yet. The authors believe that the results will most likely be received the next couple of months and hope to present them at the conference

\section{Conclusion}

A new course pertaining to global sustainability and innovation was recently developed at a university in the southeast United States. This paper presented the findings after the course was developed and offered to students as part of core curriculum for one semester. The course will hopefully continue to evolve and the authors intend to use this forum in the future to discuss the results.

\section{Acknowledgements}

The authors wish to thank the College of Science and Technology at Georgia Southern University for award of a sustainability grant which made this project possible.

\section{Bibliography}

1. Shrivastava, $\mathrm{P}$, The role of corporations in achieving ecological sustainability, Academy of Management Review: 1995

2. Pezzey, J, Sustainable Development Concepts: An economic analysis, World Bank,:1992

3. Barbier, E, The concept of sustainable economic development, Environmental Conservation: 1987.

4. Hart, S.L, Beyond Greening: Strategies for a sustainable world, Harvard Business Review, 1997 